\title{
Characterization of Solubilized Atrial Natriuretic Peptide Receptors from Rat Olfactory Bulb and A10 Cultured Smooth Muscle Cells
}

\author{
T. R. Gibson, A. D. Zyskind, and C. C. Glembotski \\ Moiecular Biology Institute and Department of Biology, San Diego State University, San Diego, California 92182
}

\begin{abstract}
Atrial natriuretic peptide (ANP) receptors from A10 cultured vascular smooth muscle cells (VSMC) and rat olfactory bulbs have been solubilized and then pharmacologically and biochemically compared. The dissociation constant for 125 ANP(99-126) was $12.7 \mathrm{pM}$ for the VSMC-derived receptor and $164 \mathrm{pM}$ for the olfactory receptor. Competition binding between ${ }^{125}$ |-ANP(99-126) and several unlabeled ANP analogs with the soluble olfactory receptor, demonstrated a rank order potency of ANP(99-126) $=$ ANP(103-126) $>>>$ ANP(103-123). However, the rank order potency of the soluble VSMC ANP receptor was ANP(99-126) $=$ ANP(103-126) $=$ ANP(103-123). Therefore, the olfactory ANP receptor appears to require the complete $\mathrm{COOH}$-terminal sequence of ANP as compared with the VSMC ANP receptor. When the 2 soluble receptor preparations were applied to a GTP-agarose column, a portion of the olfactory ANP receptor was retained on the column and could be eluted with $5 \mathrm{~mm}$ GTP, while the VSMC ANP receptor did not adsorb to the column. Since the olfactory bulb ANP receptor has been shown to contain a binding component of $116 \mathrm{kDa}$, while the VSMC ANP receptor binding component is $66 \mathrm{kDa}$, these receptors appear to be similar to the 2 receptor classes described recently in which the $120 \mathrm{kDa}$ receptor that binds GTP is postulated to be coupled to guanylate cyclase, while the 60 $\mathrm{kDa}$ receptor does not bind GTP, is not coupled to guanylate cyclase, and may possess a hormone clearance function. Taken together, these data indicate that cyclic GMP appears to be a second messenger for ANP in the brain.
\end{abstract}

Atrial natriuretic peptide (ANP) is generally thought to be a 28 amino acid peptide released by cardiac atria that causes natriuresis, diuresis, and vasorelaxation (DeBold et al., 1981; Currie et al., 1983). Receptors for this hormone have been localized to the CNS by quantitative autoradiography (Quirion et al., 1984; Gibson et al., 1986). In these earlier studies, the olfactory bulb was shown to contain high levels of ANP receptors, with the highest levels in the external plexiform layer. The binding

\footnotetext{
Received Sept. 18, 1987; revised Dec. 21, 1987; accepted Dec. 21, 1987.

This work was supported by NIMH Grant MH 42761, NIH Grant NS 25037 , and American Heart Association Grant-in-Aid 84 653, with funds contributed in part by the Philadelphia and California Chapters of the American Heart Association. C.C.G. is an Established Investigator of the American Heart Association (Grant 860173). We would like to thank Gary Wildey and Linda Rinaman for developing methods used to assay the A10 VSMC ANP receptor. We would also like to thank Paul Shields and Robert Luedtke for their interest and suggestions during the course of this work.

Correspondence should be addressed to Christopher C. Glembotski, Department of Biology, San Diego State University, 5300 Campanile Drive, San Diego, CA 92182

Copyright (C) 1988 Society for Neuroscience $0270-6474 / 88 / 083067-07 \$ 02.00 / 0$
}

of ANP(99-126) to olfactory bulb slices was specific and displayed high affinity [dissociation constant $\left(K_{d}\right)=600 \mathrm{pM}$ ]. In a later study, this CNS-derived receptor was later assayed using olfactory bulb membranes and displayed similar binding characteristics $\left(K_{d}=400 \mathrm{pm}\right)$. Also, it was shown by chemical affinity cross-linking with ${ }^{125}$ I-ANP(99-126) that it contained a binding component with a molecular mass of $116 \mathrm{kDa}$ (Wildey and Glembotski, 1986). In contrast, a vascular smooth muscle cell line derived from embryonic rat thoracic aorta (A10 VSMC) was shown to express ANP receptors, possessing a higher affinity for ANP(99-126) $\left(K_{d}-50-157 \mathrm{pM}\right)$ than did the olfactoryderived receptor; the A10 cell ANP binding component was shown by photoaffinity labeling to have a molecular mass of only $60 \mathrm{kDa}$ (Napier et al., 1986; Neuser and Bellemann, 1986; Glembotski et al., 1987).

It has recently been hypothesized that there are 2 classes of ANP receptors: those that serve a clearance function (and may have other functions, yet unknown), and ANP receptors that mediate at least some of the known biological functions of ANP through the stimulation of guanylate cyclase (Maack et al., 1987; Murad et al., 1987). It has been suggested that ANP clearance receptors [which might also be described as ANP binding sites, since the second messenger (if any) is presently unknown] possess a binding component of $60 \mathrm{kDa}$, while the binding component of ANP receptors coupled to guanylate cyclase appear to be $120 \mathrm{kDa}$ (Takayanagi et al., 1987). Also, differences in the relative affinities of various ANP ligands have been reported between these putative receptor groups, with the clearance receptor possessing a greater affinity for $\mathrm{COOH}$-terminally truncated forms of ANP (Lewicki et al., 1987).

The ANP receptor from A10 smooth muscle cells appears to possess many of the proposed characteristics of the ANP clearance receptor, while the olfactory bulb receptor seems to be quite different. Therefore, it was of interest to examine both receptor species employing identical soluble receptor preparations that allow the direct comparison of binding properties, as well as chromatographic characteristics.

\section{Materials and Methods}

Materials

Synthetic peptides were obtained from Bachem [APIII (ANP(103-126)), API (ANP(103-123))] or Peninsula Labs [ANP-28 (ANP(99-126))]. (3${ }^{125}$ I-iodotyrosyl $\left.{ }^{28}\right)$ ratANP(99-126) (1960-2090 Ci/mmol) was obtained from Amersham. All other reagents were obtained from Sigma Chemical Co. or Fisher Scientific and were reagent grade or better.

\section{Cell culture}

The smooth muscle cell line (A10, ATCC CRL 1476) was grown in Dulbecco's Modified Eagle's Medium (Grand Island Biological Co.) 


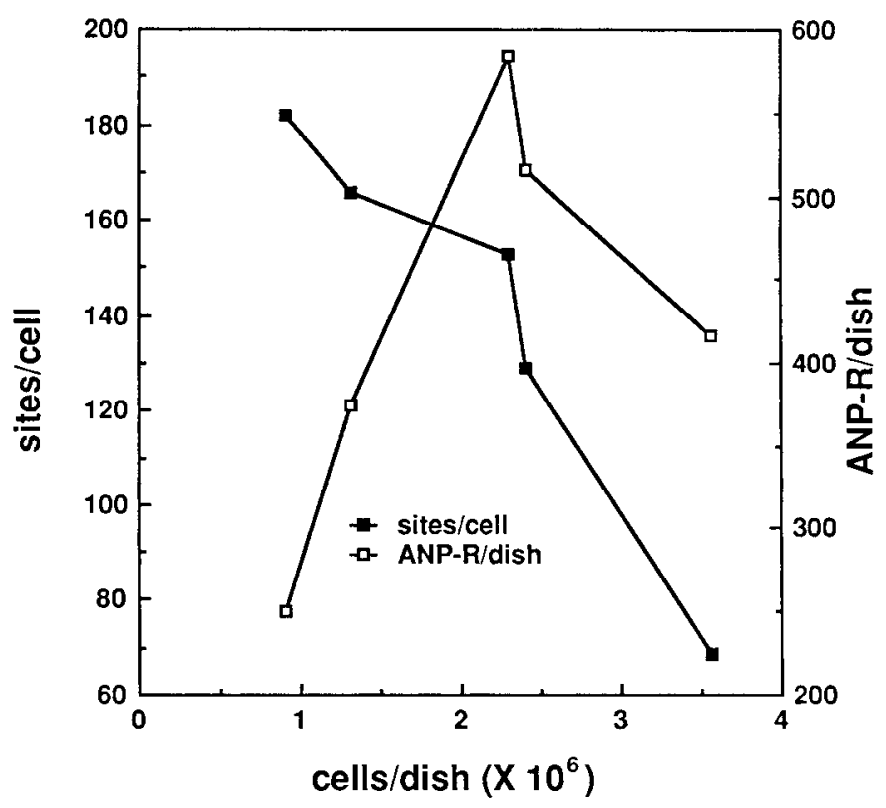

Figure 1. Number of ANP receptors on A10 VSMC cells in cultures of various cell densities. Cultures were seeded at various cell densities and harvested $5 \mathrm{~d}$ later. Each culture was treated as described in Materials and Methods. The data are presented as the number of ANP receptors per cell (sites/cell) and as the number of ANP receptors per culture dish (ANP-R/dish) plotted against the culture density (cells/ dish). Each data point is the average of 2 culture dishes.

containing 15\% fetal calf serum (Hyclone). The cells were used for the preparation of soluble ANP receptor at approximately $75 \%$ confluence $\left(2-3 \times 10^{6}\right.$ cells $/ 135 \mathrm{~mm}$ petri dish) and were utilized within 15 passages (1:5 split) after obtaining the original culture.

\section{Solubilization of receptors}

The solubilization and column chromatography of ANP receptors were performed by modifying techniques described previously (Kuno et al., 1986). All procedures were performed at $4^{\circ} \mathrm{C}$. A 10 cell membranes were prepared by first scraping the cells off the culture plates with a rubber policeman into $5 \mathrm{ml}$ of buffer $1(50 \mathrm{~mm}$ Tris, ( $\mathrm{pH} 7.6,1 \mathrm{~mm}$ EDTA, 1 $\mathrm{mm}$ dithiothreitol, and $1 \mathrm{~mm}$ phenylmethylsulfonyl fluoride) per 700 $\mathrm{cm}^{2}$ of culture area in $135 \mathrm{~mm}$ petri dishes. The plates were then washed with $5 \mathrm{ml}$ of buffer 1 , and the pooled cells were centrifuged (Dynac, Clay-Adams) at speed 50 for $5 \mathrm{~min}$. The cells were resuspended in 12.5 $\mathrm{ml}$ buffer $1 / \mathrm{gm}$ of cells (wet weight) and then homogenized (UltraTurrax, Janke and Kunkle) at $70 \%$ power for 30 sec. Olfactory membranes were prepared by collecting rat olfactory bulbs immediately after decapitation. The tissue was resuspended in the same relative volume of buffer 1 as A10 cells (above) and then homogenized in a Teflon homogenizer until totally dispersed.

The membranes derived from A1 0 cells and olfactory bulbs were then washed by centrifuging for $10 \mathrm{~min}$ at $30,000 \times \mathrm{g}$, resuspending in $8 \mathrm{ml}$ buffer 1 , and centrifuging again. The membranes were resuspended in the original volume ( $12.5 \mathrm{ml}$ buffer $1 / \mathrm{gm}$ cells), and $4 \%$ Lubrol-PX was added to a final concentration of $0.4 \%$ with stirring to solubilize membrane proteins. The mixture was stirred for $1 \mathrm{hr}$ and then centrifuged at $100,000 \times g$ for $1 \mathrm{hr}$ to remove unsolubilized material. To the supernatant were added phosphatidyl choline (to $0.025 \%$ ), glycerol (to $20 \%$ ), and $\mathrm{NaCl}$ (to $125 \mathrm{~mm}$ ) in order to stabilize the solubilized receptor for storage at $-70^{\circ} \mathrm{C}$. Solubilized receptor was kept at $20,4,-20$, and $-70^{\circ} \mathrm{C}$ in the presence of various combinations of the additives listed above, and receptor stored under the above conditions was stable for several months (not shown).

\section{Soluble receptor binding assay}

In routine assays, receptor (normally $1 \mu \mathrm{g}$ of VSMC-derived or $3.5 \mu \mathrm{g}$ of olfactory-derived protein) was added to approximately $100 \mathrm{pM}^{125} \mathrm{I}$ ANP $(28-32 \mathrm{~K} \mathrm{cpm})$ in $50 \mu 1$ of assay buffer $(100 \mathrm{~mm}$ TES, $100 \mathrm{~mm}$ PIPES, pH 7.5, 1 mM EDTA, $5 \mathrm{mM} \mathrm{MgCl}_{2}, 150 \mathrm{~mm} \mathrm{NaCl}, 0.1 \%$ Lubrol-
PX, and $0.015 \%$ phosphatidyl choline). Unlabeled ANP(99-126) (10 $\mathrm{nM}$ ) was added to assays determining non-specitic binding. Assays were incubated for $1 \mathrm{hr}$ at $30^{\circ} \mathrm{C}$, and the reaction stopped by dilution with 4 $\mathrm{ml}$ of $10 \mathrm{~mm}$ Tris ( $\mathrm{pH} \mathrm{7.5)}$. This mixture was then vacuum-filtered through glass fiber filters and quantified by gamma-counting. When binding of ${ }^{125}$ I-ANP(99-126) to the ANP receptor preparations was examined at various times of incubation, it was determined that equilibrium was attained after $20 \mathrm{~min}$ at $30^{\circ} \mathrm{C}$ (not shown).

\section{Receptor density vs cell number}

Culture dishes were seeded with Al0 cells at different densities and allowed to grow for $5 \mathrm{~d}$. The cells were then scraped into buffer 1 , homogenized as described for receptor solubilization (above), and assayed for binding activity. Parallel dishes seeded at the same densities were used to determine the number of cells/dish by treatment with trypsin and hemacytometer counting.

\section{Column chromatography}

$D E A E$-agarose. DEAE-agarose resin (Sigma Chemical Co.) was poured into $0.75 \times 6 \mathrm{~cm}$ columns and equilibrated with a buffer containing 50 mM Tris ( $\mathrm{pH} 7.6$ ), $1 \mathrm{~mm}$ EDTA, $1 \mathrm{~mm}$ dithiothreitol, $0.1 \mathrm{~mm}$ phenylmethylsulfonyl fluoride, $0.03 \%$ Lubrol-PX, $0.015 \%$ phosphatidyl choline, and 20\% glycerol. Soluble ANP receptor (150 $\mu \mathrm{g}$ VSMC, $700 \mu \mathrm{g}$ olfactory) was applied to the column, and 10-250 $\mu$ l fractions were collected. The eluant was then changed to a similar buffer but one containing $0.05 \mathrm{~m} \mathrm{NaCl}$, and 10 fractions were again collected. This was repeated with buffers containing $0.1,0.15,0.2$, and $0.25 \mathrm{M} \mathrm{NaCl}$. An aliquot $(100 \mu \mathrm{l})$ of each fraction was then assayed for binding activity as described above.

WGA-agarose. Wheat germ agglutinin-agarose (Sigma Chemical Co.) was poured into a $0.75 \times 6 \mathrm{~cm}$ column and equilibrated with a buffer containing $20 \mathrm{~mm}$ HEPES ( $\mathrm{pH} 7.4$ ), $1 \mathrm{~mm}$ EDTA, 1 mM dithiothreitol, $0.1 \mathrm{~mm}$ phenylmethylsulfonyl fluoride, $0.1 \%$ Lubrol-PX, $0.025 \%$ phosphatidyl choline, $0.5 \mathrm{M} \mathrm{NaCl}$, and $20 \%$ glycerol. Soluble ANP receptor (150 $\mu \mathrm{g}$ VSMC, $700 \mu \mathrm{g}$ olfactory) was then applied to the column, and 12-500 $\mu \mathrm{l}$ fractions were collected. The buffer was then changed to one containing 0.25 м $N$-acetylglucosamine, and 12 more fractions were collected. An aliquot $(100 \mu \mathrm{l})$ was then assayed for binding activity as described above.

GTP-agarose. Application and elution of ANP receptor from GIPagarose resin (Sigma Chemical Co.) was performed identically to the WGA-agarose resin (above) except the column was equilibrated in a buffer containing $20 \mathrm{~mm}$ Tris (pH 7.6), $1 \mathrm{~mm}$ dithiothreitol, $0.1 \mathrm{~mm}$ phenylmethylsulfonyl fluoride, $0.1 \%$ Lubrol-PX, $0.025 \%$ phosphatidyl choline, $2 \mathrm{~mm} \mathrm{MnCl}_{2}, 1 \mathrm{mM} \mathrm{NaN}_{3}$, and $20 \%$ glycerol, and that after the first 12 fractions, the buffer was changed to one containing $5 \mathrm{~mm}$ GTP. GTP added to normal assays had no effect on the binding activity of the receptor preparations.

\section{Protein determination}

The concentrations of protein in the soluble ANP receptor preparations were determined by the BCA Protein Assay (Pierce Chemical Co.) utilizing BSA as a protein standard.

\section{Results}

\section{Effects of culture density upon ANP receptor number}

The optimal density of A10 cells in culture was determined in order to produce the maximal number of VSMC ANP receptors/ culture. In Figure 1 it is apparent that the number of receptor binding sites per cell displayed an inversc rclationship to the density of cells in the culture dish. Thus, although the maximal number of receptors per cell (about 182) was achieved at very low culture densities, the number of total receptors in these cultures was low. Therefore, cultures at densities of $2-3 \times 10^{6}$ cells/culture were used in later experiments in order to maximize the number of receptors/culture.

\section{Solubilization of VSMC and olfactory ANP receptors}

The solubilization of ANP receptors from the A10 vascular smooth muscle cell line (VSMC) and from olfactory tissue was 


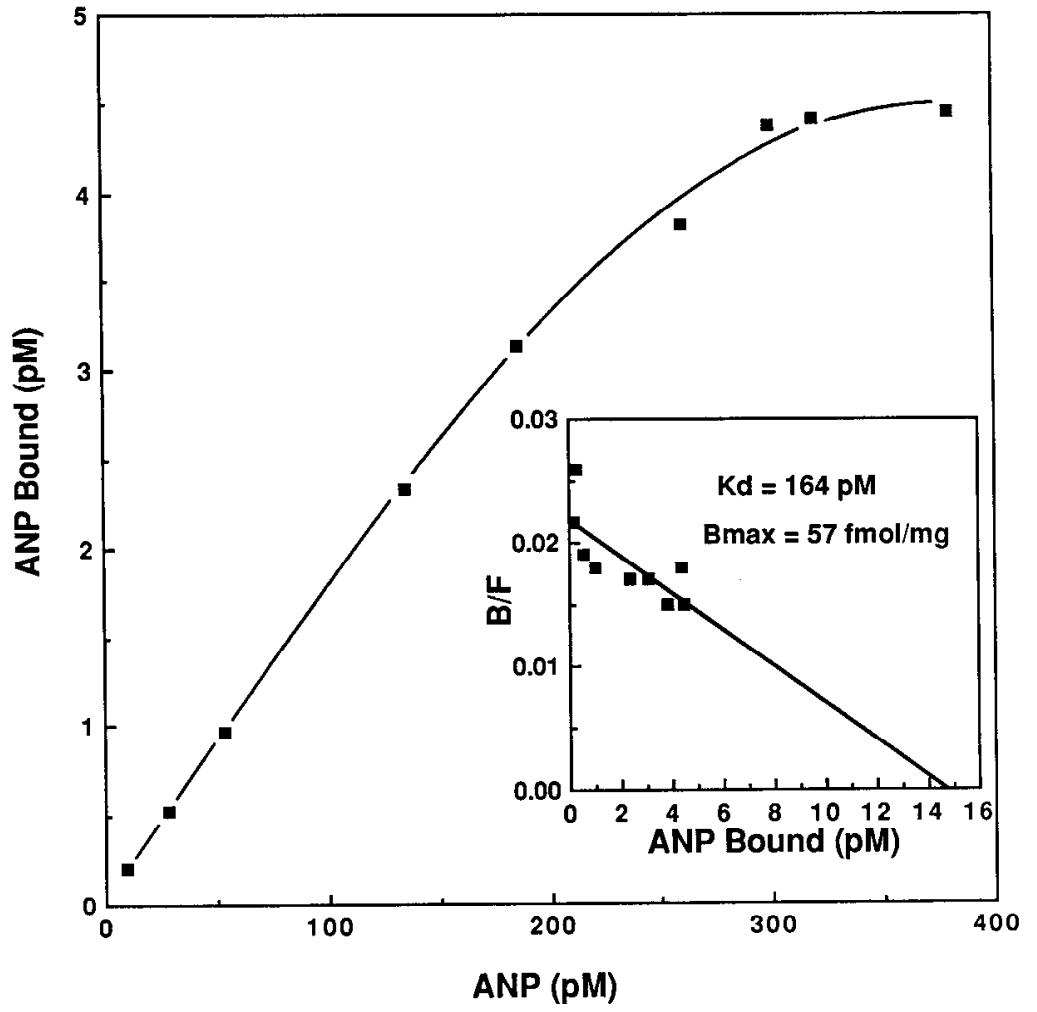

Figure 2. Saturation analysis of soluble rat olfactory ANP receptor. The saturation binding of the soluble rat olfactory ANP receptor preparation was determined using several concentrations of ${ }^{122}$ I-ANP(99-126), followed by Scatchard analysis to determine the $K_{d}$ and $B_{\max }$. first modified to maximize the yield of ANP receptor. The protein concentration of the membrane suspension and the Lubrol concentration during solubilization were varied, and $8-10 \mathrm{mg}$ protein $/ \mathrm{ml}$ and $0.3-0.6 \% \mathrm{Lubrol}$ were found to provide optimal recoveries during solubilization of the A10 cell ANP receptor (not shown).

This modified procedure was found to provide a 2- to 3-fold purification of the ANP receptor from both sources, as well as relatively high yields. The VSMC ANP receptor was obtained in about $50 \%$ yield (Table 1 ), while the recovery of the olfactory ANP receptor was about $60 \%$ (Table 2 ). The solubilization procedure did not appear to have a radical effect on the binding properties of the receptors since they maintained their highaffinity (pM) binding and rank order of potency (see below).

\section{Pharmacological characterization of ${ }^{125}$ I-iodoANP binding to solubilized $A N P$ receptors}

Scatchard analysis revealed that the $K_{d}$ of ${ }^{125}$ I-ANP(99-126) binding to the soluble olfactory receptor (164 pM) (Fig. 2) was

Table 1. Solubilization of VSMC ANP receptor

\begin{tabular}{lcccc} 
Sample & $\begin{array}{l}\text { Protein } \\
(\mathrm{mg})\end{array}$ & $\begin{array}{l}\text { Total } \\
\text { ANP-R } \\
\text { (fmol) }\end{array}$ & $\begin{array}{l}\text { ANP-R } \\
\text { (fmol/mg) }\end{array}$ & $\begin{array}{l}\text { Recovery } \\
(\%)\end{array}$ \\
\hline Cells & 200 & 15,300 & 76.5 & 100 \\
Homogenate & 185 & 15,300 & 82.7 & 100 \\
Membranes 1 & 156 & 15,000 & 116.0 & 98 \\
Membranes 2 & 116 & 15,400 & 137.4 & 101 \\
Soluble ANP-R & 40 & 7,000 & 172.4 & 46
\end{tabular}

The cells from a hundred $135 \mathrm{~mm}$ culture plates were treated as described in Materials and Methods. Aliquots at each step were tested for specific ${ }^{125}{ }^{25}$ ANP( 99 126) binding as described in Materials and Methods. ANP-R, ANP receptor. somewhat lower than the previous detcrminations of ligand affinity, which were 600 pm in rat brain slices and 400 pM in olfactory bulb membranes (Gibson et al., 1986; Wildey and Glembotski, 1986). The $K_{d}$ of the VSMC ANP receptor employing the same ligand was also shown to be somewhat lower than previously described in other systems, 12.7 pM (Fig. 3) versus 50-157 pM (Napier et al., 1986; Neuser and Bellemann, 1986). As expected, the $B_{\max }$ of the VSMC ANP receptor preparation was greater than the olfactory-derived receptor, as can also be seen in Tables 1 and 2 . The receptor appears to be present in lower concentration in olfactory tissue, since the entire bulb is homogenized for the preparation of soluble receptor, much of which contains relatively low levels of ANP receptor (Gibson et al., 1986).

Inhibition constants for 2 ANP analogs, as well as ANP(99126), were also determined. When the soluble olfactory ANP receptor was tested, the $K_{i}$ valucs for $\operatorname{ANP}(99-126)$ and ANP(103-126) were 254 and 267 pM, respectively. However, the $K_{i}$ for ANP(103-123) was 1515 pM, significantly different from the competitors with intact $\mathrm{COOH}$-termini (Fig. 4A). In contrast, the soluble VSMC ANP receptor yielded $K_{i}$ values for ANP(99-126), ANP(103-126), and ANP(103-123) that were

\begin{tabular}{lllll}
\hline Table 2. Solubilization of rat olfactory bulb ANP receptor \\
& \multicolumn{5}{c}{$\begin{array}{l}\text { Total } \\
\text { Protein } \\
\text { (mg) }\end{array}$} & $\begin{array}{l}\text { ANP-R } \\
\text { (fmol) }\end{array}$ & $\begin{array}{l}\text { ANP-R } \\
\text { (fmol/mg) }\end{array}$ & $\begin{array}{l}\text { Recovery } \\
(\%)\end{array}$ \\
\hline Sample & 74 & 700 & 9.5 & 100 \\
Memogenate & 67 & 700 & 10.0 & 100 \\
Membranes 1 & 43 & 670 & 15.6 & 96 \\
Soluble ANP-R & 15 & 420 & 28.0 & 60
\end{tabular}

Olfactory bulbs from 20 rats were treated as described in Materials and Methods. 
Figure 3. Saturation analysis of soluble VSMC ANP receptor. The saturation binding of the soluble VSMC ANP receptor preparation was examined as in Figure 2.

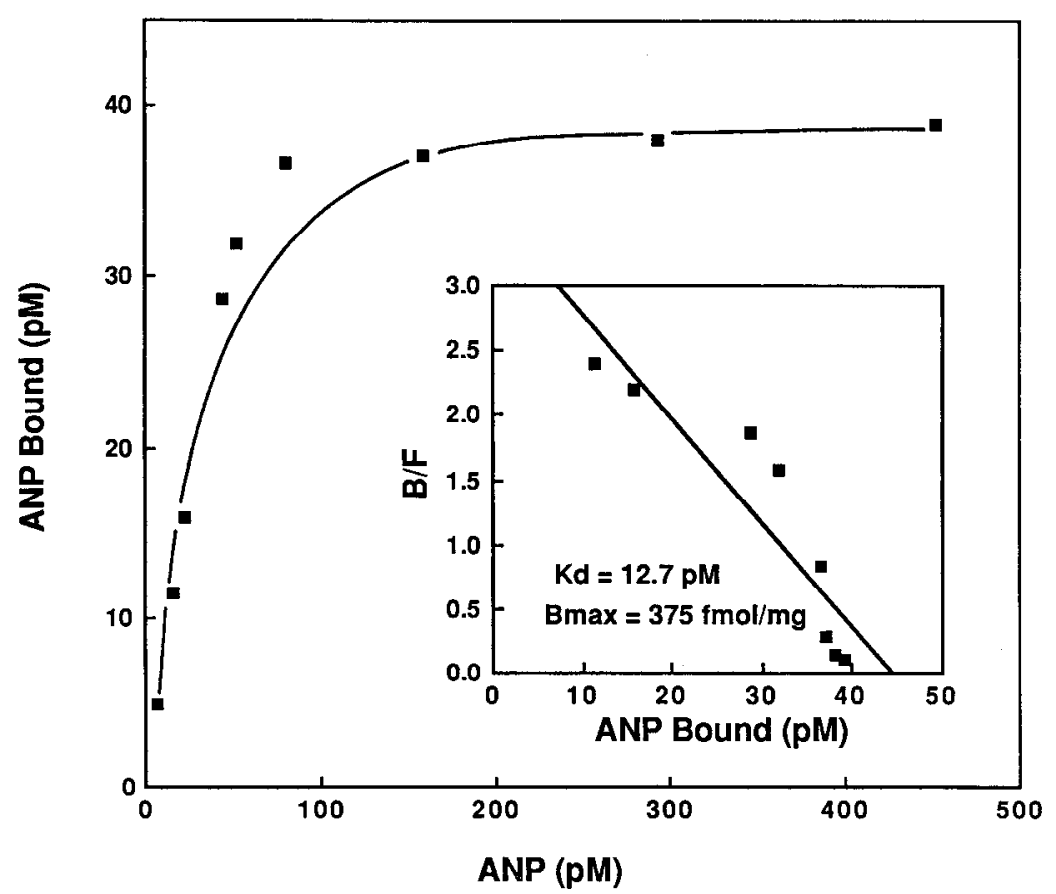

However, when the VSMC and olfactory receptor preparations were applied to GTP-agarose columns, the elution profiles were dramatically different. About $50 \%$ of the olfactory receptor bound to the resin and was eluted by $5 \mathrm{~mm}$ GTP (Fig. 6A), whereas none of the VSMC ANP receptor bound to the resin under these conditions (Fig. 6B). Neither receptor preparation bound to GDP- or ATP-agarose, and the elution of the soluble olfactory ANP receptor from the GTP-agarose required GTP; ATP and GDP did not elute the receptor from the column. The proportion of olfactory receptor that bound to the GTP-agarose resin remained constant when different amounts of resin or receptor preparation were used. Therefore, it appears that the olfactory receptor preparation may be heterogeneous with respect to binding of GTP. The VSMC receptor, however, passed directly through the column in the void volume, and thus did not appear to have any GTP binding activity (Fig. 6B). agarose columns and eluted with step gradients of $\mathrm{NaCl}$ (Fig. $5 A$ ). The binding activity from each receptor source exhibited a major peak eluting at $0.15 \mathrm{M} \mathrm{NaCl}$, with minor peaks flanking the primary peak. Therefore, no detectable charge differences were apparent at $\mathrm{pH} 7.5$.

Another possibility for the differences in binding properties might be differences in glycosylation between the 2 receptors. Both receptor preparations efficiently bound to wheat germ agglutinin-agarose and eluted with $0.25 \mathrm{M} N$-acetylglucosamine (Fig. $5 B$ ). Attempts to differentiate the degrees of glycosylation using gradient $N$-acetylglucosamine elution did not result in differential elution (not shown). Additionally, both receptor preparations bound efficiently to concanavalin A-agarose and eluted at similar concentrations of methyl $\alpha$-D-mannopyranoside (not shown). Other columns were also used (phenyl-agarose, blue dextran-agarose, reactive red-agarose), and the soluble VSMC and olfactory receptor eluted identically from these resins (not shown). This would indicate that the biochemical properties of the ANP receptors from these 2 sources are very similar, suggesting that these receptors may have amino acid sequences in common.

\section{Discussion}

Previous reports have indicated that ANP receptors from a variety of tissues possess different affinities for the circulating form of the hormone [ANP(99-126)] and its analogs (Hirata et al., 1984; Ballermann et al., 1985; De Lean et al., 1985; Hirose et al., 1985; Misono et al., 1985; Murphy et al., 1985; Schenk et al., 1987). It has also been shown that in several tissues the $K_{d}$ for ANP, as measured in binding assays, can differ from the $\mathrm{EC}_{50}$ for guanylate cyclase stimulation by as much as 100 -fold (Hirata et al., 1984; Leitman and Murad, 1986; Neuser and Bellemann, 1986). From these data it has been hypothesized that 2 classes of ANP receptors exist; one is of high affinity and is not coupled to guanylate cyclase, while the other displays a relatively low affinity and is coupled to guanylate cyclase (Scarborough et al., 1986).

The presence of 2 different ANP receptors has been demonstrated in cultured endothelial cells (Leitman et al., 1986). In that report, the ability of ANP(101-126) to stimulate guanylate 

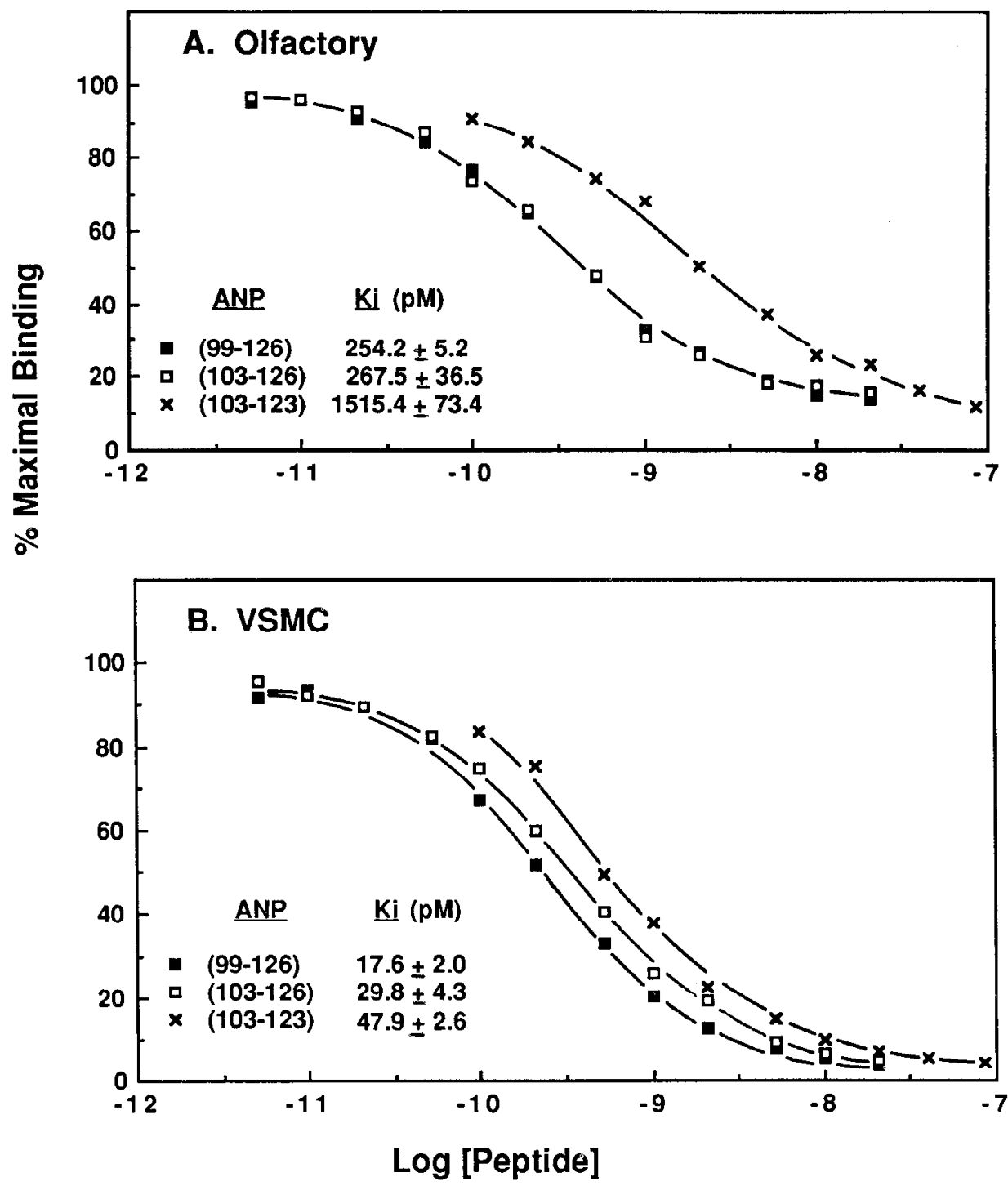

Figure 4. Soluble ANP receptor competition binding. The binding of ${ }^{125} \mathrm{I}$ ANP(99-126) to the soluble VSMC and olfactory bulb ANP receptor preparations was examined in the presence of various concentrations of unlabeled ANP(99-126), ANP(103-126), and ANP(103-123). The $K_{i}$ values were determined utilizing the Cheng-Prusoff correction (Cheng and Prusoff, 1973), using the $K_{d}$ values determined in Figures 2 and 3 . The $K_{i}$ determinations are given \pm SEM. An analysis of variance and Newman-Keuls post hoc analysis demonstrated significant differences $(p$ $<0.01$ ) between the $K_{i}$ values of all competitors of the olfactory ANP receptor versus the VSMC receptor, and the $K_{i}$ value of ANP(103-123) inhibition of the olfactory receptor was significantly different $(p<0.01)$ from all other competitors from either source.

cyclase was examined after either ANP(101-126) or ANP(103123) had becn used to block the receptors by cross-linking. It was shown that blocking by ANP(101-126) decreased the ANP(101-126) stimulation of guanylate cyclase by $60 \%$, while blocking by ANP(103-123) had no effect. The authors concluded that 1 of the 2 species of ANP receptor (shown to be $66 \mathrm{kDa}$ ) was not coupled to guanylate cyclase and possessed similar affinities for ANP(101-126) and ANP(103-123). The other receplor (shown to be $130 \mathrm{kDa}$ ) was capable of stimulating guanylate cyclase and required ANP(101-126) for binding and activity. It has also been shown previously that guanylate cyclase-coupled ANP receptors from rat lung and adrenal can copurify with particulate guanylate cyclase by affinity chromatography on GTP-agarose and possesses ANP binding components of approximately $120 \mathrm{kDa}$ (Kuno et al., 1986; Paul et al., 1987; Takayanagi et al., 1987). It is not clear whether the $120 \mathrm{kDa}$ ANP receptor and particulate guanylate cyclase are a single polypeptide or if they are 2 separate proteins that are tightly bound.

In the present study, a peripheral tissue-derived $66 \mathrm{kDa}$ ANP receptor (from A10 vascular smooth muscle cells) and a CNS- derived $116 \mathrm{kDa}$ ANP receptor (from rat olfactory bulbs) were examined to compare the binding and physical characteristics of the 2 receptor preparations. When the binding of ${ }^{125}$ I-ANP(99126) to the receptors was examined, the soluble VSMC ANP receptor had a greater affinity for the radioligand than did the soluble olfactory ANP receptor. Also, when unlabeled ANP and ANP analogs were used to compete for ${ }^{125}$ I-ANP(99-126) binding, it was found that the inhibition constant for ANP(99-126) was lower for the VSMC ANP receptor than for olfactory ANP receptor. However, the olfactory receptor was inhibited by ANP(103-123, $\left.K_{t}=1515 \mathrm{pM}\right)$ significantly less effectively than ANP(99-126, $\left.K_{i}=254 \mathrm{pM}\right)$, in contrast to the VSMC ANP receptor ( $K_{i}=48$ pM vs. 18 pM, respectively). Column chromatography of the 2 soluble ANP receptor preparations in the present study yielded generally identical elution profiles, indicating that most physical characteristics of the examined receptors are very similar. Chromatography on GTP-agarose resin, however, produced a reproducible division of the olfactory ANP receptor preparation into 2 components, one of which did not interact with the resin and the other which was bound to the resin and could be eluted with $5 \mathrm{~mm}$ GTP. Thus, about one- 

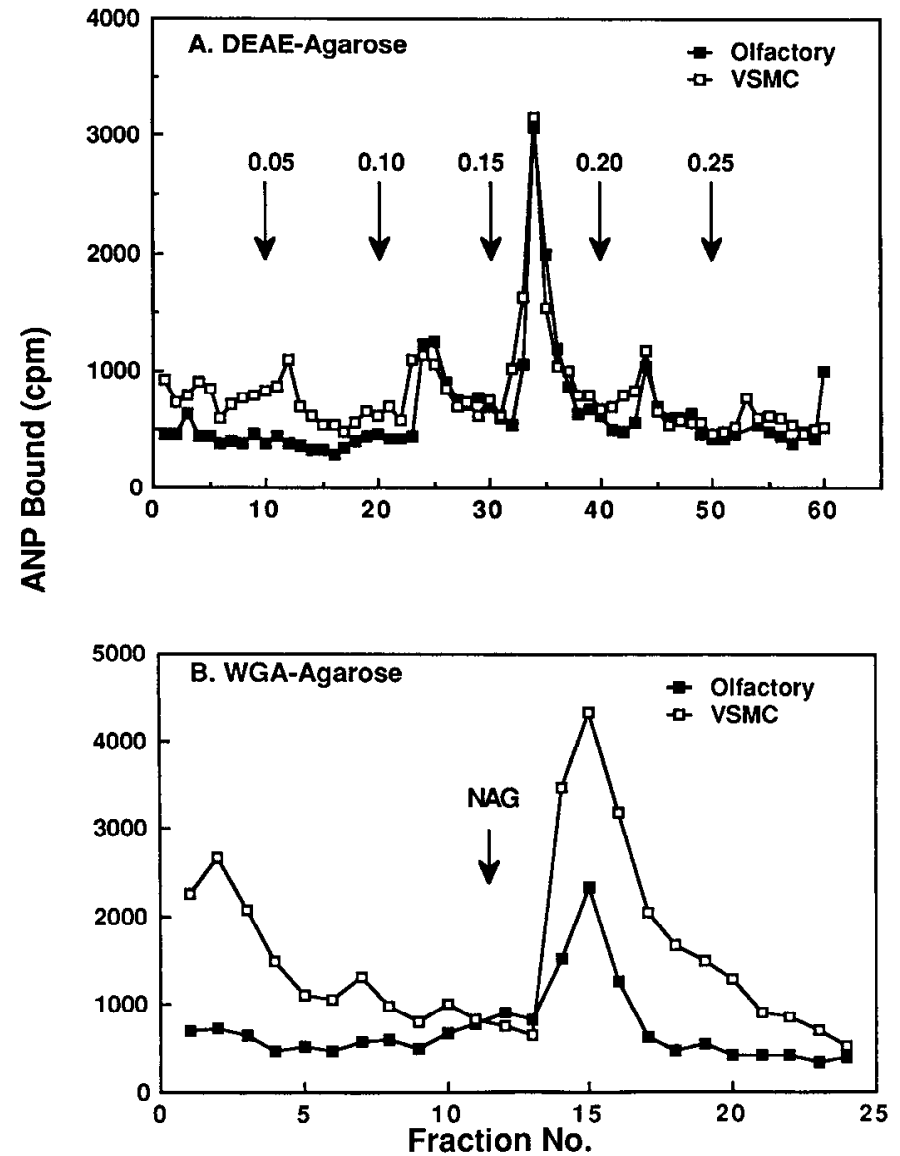

Figure 5. DEAE- and WGA-agarose elution profiles of VSMC and olfactory bulb soluble ANP receptor preparations. The chromatography was performed as described in Materials and Methods. The average recoveries of ANP binding activity were 99\% (DEAE) and 65\% (WGA).

half of the olfactory ANP receptor preparation was capable of binding GTP as opposed to the VSMC ANP receptor, which apparently had no GTP binding capability.

It appears, therefore, that the majority of high-affinity (pM) ANP receptors from A10 VSMC cells do not bind to GTP, and thus may not be coupled to guanylate cyclase. However, cGMP levels can be increased in A10 VSMC cells by the addition of ANP (Napier et al., 1986). The $\mathrm{EC}_{50}$ for this stimulation is much higher than $K_{d}$ reported here, and the receptors responsible for this stimulation would not be detected utilizing the methods described in this report. The uncoupled A10 VSMC receptor, with its relatively high concentration and similar affinities for a variety of ANP peptides, has been speculated to provide a clearance function, removing ANP from the circulation after it is no longer needed (Maack et al., 1987). However, other, as yet unknown functions for this receptor have not been ruled out (Inagami et al., 1987). In contrast, the olfactory bulb tissue appears to possess a complement of ANP receptors similar to the vascular endothelium or rat lung, and might be a mixture of receptors, some of which are coupled to guanylate cyclase and some of which are not. The stimulation of guanylate cyclase by ANP has been hypothesized to result in many of the known biological activities of ANP (Murad et al., 1987). In the CNS, ANP has been shown to increase cGMP levels in several neural cell lines (Friedl et al., 1986). Since a component of the ANP receptors from the olfactory bulb binds to GTP, it is possible
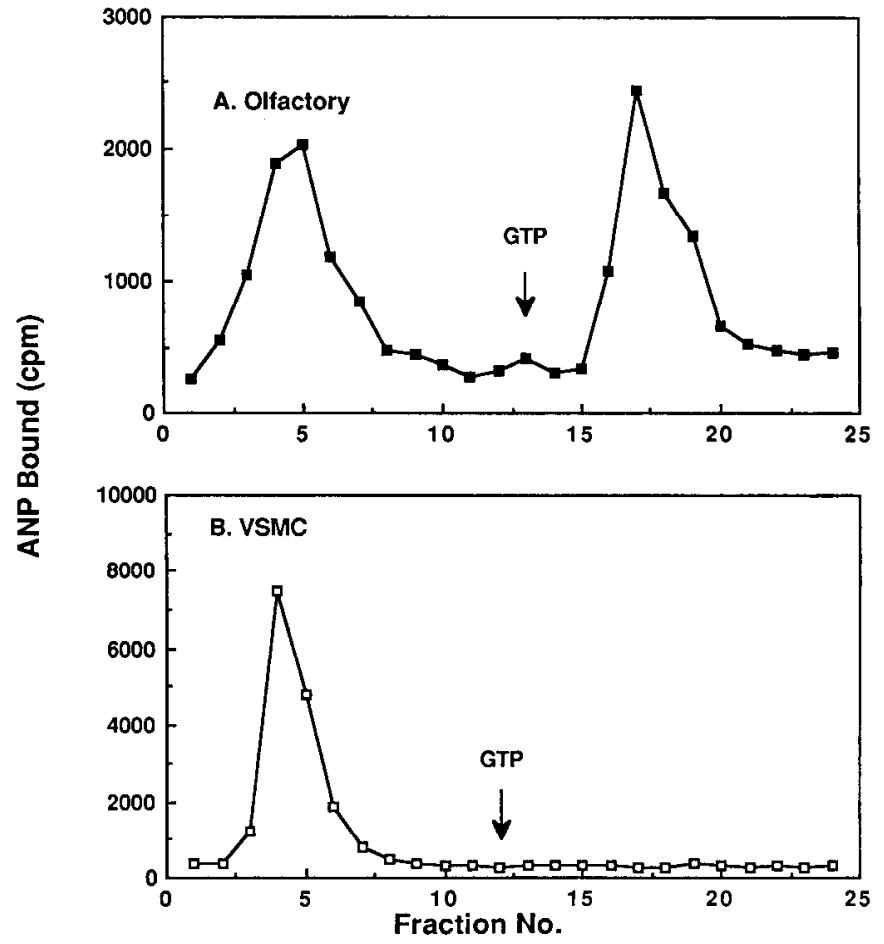

Figure 6. GTP-agarose elution profile of VSMC and olfactory bulb soluble ANP receptor preparations. The chromatography was performed as described in Materials and Methods. The average recovery of ANP binding activity was $87 \%$.

that this tissue utilizes cGMP as an intracellular messenger following ANP binding. Also, the olfactory bulbs are behind the blood-brain barrier, and the ANP receptors examined from this tissue would thus be expected to interact with CNS-derived ANP. It has recently been shown that ANP mRNA is present in various regions of the brain, indicating that ANP is produced within the CNS (Gardner et al., 1987) and that ANP is present within olfactory bulbs (Kawata et al., 1986). Thus, ANP may be acting as a neurotransmitter or neuromodulator in the olfactory bulb, although its function in this tissue remains to be determined.

\section{References}

Ballermann, B. J., R. L. Hoover, M. J. Karnovsky, and B. M. Brenner (1985) Physiologic regulation of atrial natriuretic peptide receptors in rat renal glomeruli. J. Clin. Invest. 76: 2049-2056.

Cheng, Y. C., and W. H. Prusoff (1973) Relationship between the inhibition constant $\left(\mathrm{K}_{\mathrm{i}}\right)$ and the concentration of inhibitor which causes 50 percent inhibition $\left(I_{50}\right)$ of an enzymatic reaction. Biochem. Pharmacol. 22: 3099-3108.

Currie, M. G., D. M. Geller, B. R. Cole, J. G. Boylan, W. YuSheng, S. W. Holmberg, and P. Needleman (1983) Bioactive cardiac substances: Potent vasorelaxant activity in mammalian atria. Science 221: 71-73.

DeBold, A. J., H. B. Borenstein, A. T. Veress, and H. Sonnenberg (1981) A rapid and potent natriuretic response to intravenous injection of atrial myocardial extract in rats. Life Sci. 28: 89-94.

De Lean, A., G. Thibault, N. G. Seidah, C. Lazure, J. Gutkowska, M. Chretien, J. Genest, and M. Cantin (1985) Structure-activity relationships of atrial natriuretic factor (ANF). III. Correlation of receptor affinity with relative potency on aldosterone production on zona glomerulosa cells. Biochem. Biophys. Res. Commun. 132: 360-367.

Friedl, A., C. Harmening, and B. Hamprecht (1986) Atrial natriuretic hormones raise the level of cyclic GMP in neural cell lines. J. Neurochem. 46: 1522-1527.

Gardner, D. G., G. P. Vlasuk, J. D. Baxter, J. C. Fiddes, and J. A. 
Lewicki (1987) Identification of atrial natriuretic factor gene transcripts in the central nervous system of the rat. Proc. Natl. Acad. Sci. USA 84: 2175-2179.

Gibson, T. R., G. M. Wildey, S. Manaker, and C. C. Glembotski (1986) Autoradiographic localization and characterization of atrial natriuretic peptide binding sites in the rat ce al nervous system and adrenal gland. I. Neurosci. 6: 2004-2011.

Glembotski, C. C., G. M. Wildey, and T. R. Gibson (1987) Solubilization and characterization of atrial natriuretic peptide receptors in the rat central nervous system. Cell. Mol. Neurobiol. (in press).

Hirata, Y., M. Tomita, H. Yoshimi, and M. Ikeda (1984) Specific receptors for atrial natriuretic factor (ANF) in cultured vascular smooth muscle cells of rat aorta. Biochem. Biophys. Res. Commun. 125:562568

Hirose, S., F. Akiyama, M. Shinjo, H. Ohno, and K. Murakami (1985) Solubilization and molecular weight estimation of atrial natriuretic factor receptor from bovine adrenal cortex. Biochem. Biophys. Res. Commun. 130: 574-579.

Inagami, T., R. Takayanagi, T. Imada, K. N. Pandey, R. M. Snajdar, and K. S. Misono (1987) Biochemical mechanism in the ANF producing cells and ANF target cells. Second World Congress on Biologically Active Atrial Peptides, Second Annual Meeting of the American Society of Hypertension, p. 183 (abstr. BF10).

Kawata, M., K. Nakao, N. Morii, Y. Kiso, H. Yamashita, H. Imura, and Y. Sano (1986) Atrial natriuretic polypeptide: Topographical distribution in the rat brain by radioimmunoassay and immunohistochemistry. Neuroscience 16: 521-546.

Kuno, T., J. W. Andresen, Y. Kamisaki, S. A. Waldman, L. Y. Chang, S. Saheki, D. C. Leitman, M. Nakane, and F. Murad (1986) Copurification of an atrial natriuretic factor receptor and particulate guanylate cyclase from rat lung. J. Biol. Chem. 261: 5817-5823.

Leitman, D. C.., and F. Murad (1986) Comparison of binding and cyclic GMP accumulation by atrial natriuretic peptides in endothelial cells. Biochim. Biophys. Acta 885: 74-79.

Leitman, D. C., J. W. Andresen, T. Kuno, Y. Kamisaki, J.-K. Chang, and F. Murad (1986) Identification of multiple binding sites for atrial natriuretic factor by affinity cross-linking in cultured endothelial cells. J. Biol. Chem. 261: 11650-11655.

Lewicki, J., R. Scarborough, F. Fuller, G. Porter, M. Suzuki, F. Almeida, T. Maack, and D. Schenk (1987) Pharmacological and biochemical studies of ANF receptor subpopulations. Second World Congress on Biologically Active Atrial Peptides, Second Annual Meeting of the American Society of Hypertension, p. 184 (abstr. BF12).
Maack, T., M. Suzuki, F. A. Almeida, D. Nussenzveig, R. M. Scarborough, G. A. McEnroe, and J. A. Lewicki (1987) Physiological role of silent receptors of atrial natriuretic factor. Science 238: 675-678.

Misono, K. S., R. T. Grammer, J. W. Rigby, and T. Inagami (1985) Photoaffinity labeling of atrial natriuretic factor receptor in bovine and rat adrenal cortical membranes. Biochem. Biophys. Res. Commun. 130: 994-1001.

Murad, F., D. C. Leitman, C. Molina, and S. A. Waldman (1987) Role of guanylate cyclase and cyclic GMP in the actions of atrial natriuretic factor. Second World Congress on Biologically Active Atrial Peptides, Second Annual Meeting of the American Society of Hypertension, $p$. 184 (abstr. BF14).

Murphy, K. M. M., L. L. McLaughlin, M. L. Michener, and P. Needleman (1985) Autoradiographic localization of atriopeptin III receptors in rat kidney. Eur. J. Pharmacol. 111: 291-292.

Napier, M. A., K. E. Arcuri, and R. L. Vandlen (1986) Binding and internalization of atrial natriuretic factor by high-affinity receptors in A10 smooth muscle cells. Arch. Biochem. Biophys. 248: 516-522.

Neuser, D., and P. Bellemann (1986) Receptor binding, cGMP stimulation and receptor desensitization by atrial natriuretic peptides in cultured A10 vascular smooth muscle cells. FEBS Lett. 209: 347351.

Paul, A. K., R. B. Marala, R. K. Jaiswal, and R. K. Sharma (1987) Coexistence of guanylate cyclase and atrial natriuretic factor receptor in a $180-\mathrm{kD}$ protein. Science $235: 1224-1226$.

Quirion, R., M. Dalpe, A. De Lean, J. Gutkowska, M. Cantin, and J. Genest (1984) Atrial natriuretic factor (ANF) binding sites in brain and related structures. Peptides 5: 1167-1172.

Scarborough, R. M., D. B. Schenk, G. A. McEnroe, A. Arfsten, L.-L. Kang, K. Schwartz, and J. A. Lewicki (1986) Truncated atrial natriuretic peptide analogs. J. Biol. Chem. 261: 12960-12964.

Schenk, D. B., M. N. Phelps, J. G. Porter, F. Fuller, B. Cordell, and J. A. Lewicki (1987) Purification and subunit composition of atrial natriuretic peptide receptor. Proc. Natl. Acad. Sci. USA 84: 15211525.

Takayanagi, R., R. M. Snajdar, T. Imada, M. Tamura, K. N. Pandey, K. S. Misono, and T. Inagami (1987) Purification and characterization of two types of atrial natriuretic factor receptors from bovine adrenal cortex: Guanylate cyclase-linked and cyclase-free receptors. Biochem. Biophys. Res. Commun. 144: 244-250.

Wildey, G. M. and C. C. Glembotski (1986) Cross-linking of atrial natriuretic peptide to binding sites in rat olfactory bulb membranes. J. Neurosci. 6: 3767-3776. 